\title{
Gambaran Leukosit Darah Ikan Koi (Cyprinus carpio) yang Terinfestasi Ichthyophthirius multifiliis pada Derajat Infestasi yang Berbeda dengan Metode Kohabitasi
}

\section{Leukocyte Profil of Koi Fish (Cyprinus carpio) Which Infested by Ichthyophthirius multifiliis on The Different Infestation Degree With Cohabitation Methode}

\author{
Gunanti Mahasri, Pristita Widyastuti dan Laksmi Sulmartiwi \\ Fakultas Perikanan dan Kelautan Universitas Airlangga \\ Kampus C Mulyorejo - Surabaya, 60115 Telp. 031 - 5911451
}

\begin{abstract}
Koi fish (Cyprinus carpio) is one type of ornamental fresh water, which much liked because of its beauty such as have shape, colour and beautiful patern, so many people depend on their life from culturing and marketing koi fish. The main obstacle in koi fish culture is disease attack. The disease caused by interaction between host, pathogen and environment (Fisheries and Marine Department, 2005).

Ichthyophthirius multifiliis (I. multifiliis) is one of parasite which can cause fish ichtyopthiriasis. According Durborow (1998) said, that clinical sign of koi fish who affected by I. multifiliis had a white spot. I. multifiliis is a parasite that eat blood cells (Dogiel et al., 1970). According Macdonald et al., (2001) in Saptanto (2004) explain, that parasite infestation also could increase eosinophile. Total of monocyte increases if there are a foreign substantion in tissue or blood circulation and neutrophile are phagocyte which could migration in the other tissue to eat bacteria (Moyle and Chech, 2004). Meyer and Harvey (1998) in Salasia (2001) assert, that blood test also useful to help disease diagnose, examining immune system and to determine fish health status.

The method was used in this field research is experimental method by cohabitation method. This research is expected to provide information and knowledge about leucocyte component which infested by I. multifiliis at different infestation level with cohabitation method. This research was done July 26, 2010 until December 31, 2010 at Klepon Village, District of Garum, Blitar, East Java and in the Laboratory of Education Faculty of Fisheries and Marine Fisheries, Airlangga University, Surabaya.

I. multifiliis infestation level are classified based on the total of I. multifiliis who infestation koi fish total of low: 1-5 parasites/slide, medium: 6-10 parasites/slide, High: more than 11 parasites/slide (Margolis et al., 1982 in Akter dkk., 2007). The result of research showed that chages of leucocyte blood profil of the amount the total each leucocyte component (lymphocyte, neutrophile, monocyte, eosinophile) koi fish who infested by I. multifiliis, there is a declining in average percentage of total lymphocyte in low infestation $86.20 \%$, medium infestation $79.40 \%$ and heavy infestation $75.20 \%$. The average percentages of total monocyte was increasing in low infestation $5.40 \%$, medium infestation $5.60 \%$ and heavy infestation $6.60 \%$. The average percentages of total neutrophile also increasing in low infestation $6.40 \%$, medium infestation $11.20 \%$ and heavy infestation $11.60 \%$. The average percentages of total eosinophile also increasing in low infestation $2.00 \%$, medium infestation $3.60 \%$ and heavy infestation $5.60 \%$. water quality measured during research, the average of temperature $24-26^{\circ} \mathrm{C}$ and $\mathrm{pH}$ cohabitation 8 .
\end{abstract}

Keywords : Ichthyopthirius multifiliis, Leukocyte Profil of Koi Fish, Cohabitation

\section{Pendahluan}

Ikan koi (C. carpio) merupakan salah satu jenis ikan hias air tawar yang banyak disenangi karena keindahannya seperti memiliki bentuk, warna dan corak yang indah, sehingga banyak orang menggantungkan hidupnya dengan membudidayakan dan memasarkan ikan koi. Penjualan budidaya pada pembesaran ikan koi tahun 2010 dapat menghasilkan pendapatan Rp.7.628.000,00.-/tahun dari penjualan 551 ekor ikan koi (Wijanarko, 2009) dan harga ikan koi pada tahun 2009 termasuk dalam kategori ikan mahal antara Rp.20.000,00.- hingga Rp.40.000.000,00.- (Sinartani, 2010) dengan sistem penjualan per ekor (Galeriukm, 2010).

Kendala utama dalam budidaya ikan koi adalah serangan penyakit. Penyakit tersebut timbul karena suatu interaksi antara inang, patogen dan lingkungan. Ichthyophthirius multifiliis merupakan salah satu parasit yang dapat menyebabkan ichthyopthriasis pada ikan. Penyakit ini dapat menyerang ikan koi, dapat menyebabkan kematian mencapai $100 \%$ populasi dalam waktu yang relatif singkat pada benih (Huda, 2008). Daerah penyerangan terjadi pada lapisan kulit, sirip dan insang. Menurut Durborow (1998) mengatakan, bahwa gejala klinis ikan koi yang terkena $I$. multifiliis yaitu adanya bintik-bintik putih (white spot).

Berdasarkan Kep.Men No.17/ Men/2003 I. multifiliis merupakan penyebab penyakit ikan yang perlu mendapatkan perhatian, karena dapat menyerang semua jenis ikan air tawar. Adanya perdagangan ikan secara bebas memudahkan suatu habitat ikan terserang I. multifiliis (Wahyuni, 2007). 
I. multifiliis merupakan parasit yang memakan sel-sel darah (Dogiel et al., 1970). Ikan yang terinfestasi $I$. multifiliis menunjukkan adanya perubahan jumlah leukosit (sel darah putih). Komponen leukosit yang berhubungan dengan infeksi parasit yaitu eosinofil sehingga dengan meningkatnya eosinofil menandakan banyaknya parasit (Roberts, 1989). Namun menurut Macdonald et al., (2001) dalam Saptanto (2004) menjelaskan, bahwa infestasi parasit juga dapat memacu peningkatan eosinofil. Jumlah monosit akan meningkat jika ada substansi asing pada jaringan atau sirkulasi darah dan neutrofil bersifat fagosit yang dapat bermigrasi kejaringan lain untuk memakan bakteri (Moyle and Chech, 2004).

Peningkatan jumlah leukosit menunjukkan adanya respon perlawanan tubuh terhadap agen penyebab penyakit. Meyer dan Harvey (1998) dalam Salasia (2001) menegaskan, bahwa pemeriksaan darah juga bermanfaat untuk membantu diagnosa penyakit, meneliti sistem imun dan untuk mengetahui status kesehatan ikan. Bertitik tolak dari keterangan tersebut maka pemeriksaan darah perlu dilakukan untuk mengetahui gambaran leukosit berupa jumlah masing-masing komponen leukosit (limfosit, monosit, neutrofil, eosinofil dan basofil) ikan yang merupakan salah satu respon tubuh ikan terhadap parasit I. multifiliis.

\section{Materi dan Metode Penelitian}

Waktu dan Tempat

Penelitian ini dilakukan pada tanggal 26 Juli 2010 sampai dengan 31 Desember 2010 di Desa Klepon, Kecamatan Garum, Blitar, Jawa Timur dan kemudian dilanjutkan penghitungan leukosit di Laboratorium Pendidikan Perikanan Fakultas Perikanan dan Kelautan Universitas Airlangga Surabaya.

\section{Materi Penelitian}

Peralatan pemeliharaan ikan koi berupa kolam beton yang terdiri dari 1 kolam uji ukuran $(3 \mathrm{x}$ $2,5 \times 0,6) \mathrm{m}^{3}$ dan 1 kolam stok ikan sehat $(2 \times 1 \mathrm{x}$ $0,6) \mathrm{m}^{3}$, aerasi, selang aerasi, jaring ikan, peralatan pengukur kualitas air ( $\mathrm{pH}$ paper untuk mengukur $\mathrm{pH}$, thermometer untuk mengukur suhu air), pemerikasaan parasit dan darah menggunakan mikroskop, spuit $1 \mathrm{ml}$, pinset, objek glass, cover glass, scalpel dan hand tally counter. ikan koi sehat sebanyak 100 ekor dengan panjang kurang lebih 10 $\mathrm{cm}$ berumur 2-3 bulan dan 7 ikan yang terserang parasit I. multifiliis. Sebagai bahan untuk ulasan darah yaitu Ethylene Diamine Tetra Acetic Acid (EDTA) sebagai antikoagulan, methanol dan giemsa $20 \%$.

Metode Penelitian

Metode yang digunakan dalam penelitian ini adalah metode eksperimen yang dilakukan di lapangan dengan cara kohabitasi. Penularan penyakit dilakukan dengan metode kohabitasi yaitu melakukan pencampuran (cohabitation) dalam kurun waktu tertentu, terhadap ikan sumber penyakit dengan ikan sehat untuk mengetahui apakah penyakit tersebut dapat ditularkan secara horisontal (Prayitno dkk., 2003). Selama proses kohabitasi kondisi dipertahankan agar ikan sehat dan ikan sakit tidak mengalami kematian, sehingga dilakukan manipulasi lingkungan agar media dapat ditoleransi antara ikan dan parasit (Mahasri, 2007). Penularan ini bertujuan untuk menginfestasi ikan koi sehat dengan parasit $I$. multifiliis.

\section{Prosedur Kerja}

Persiapan Peralatan dan Media Pemeliharaan Alat yang digunakan dalam penelitian adalah kolam, batu aerasi dan selang aerasi berjumlah 4 buah. Alat yang akan digunakan dibersihkan terlebih dahulu dengan cara dicuci menggunakan sabun hingga bersih kemudian dikeringkan di bawah sinar matahari. Volume air yang digunakan sebanyak 3000 L air. Air yang akan digunakan sebagai media diendapkan semalam terlebih dahulu dengan tandon yang diaerasi.

Sampel

Penelitian ini menggunakan perbandingan 1:14 yaitu 100 ekor ikan koi sehat (tidak terinfestasi I. multifiliis) dengan panjang sekitar $10 \mathrm{~cm}$. Sampel ikan koi yang positif terserang I. multifiliis sebanyak 7 ekor. Kohabitasi sebelumnya telah dilakukan pada penelitian pendahuluan dengan perbandingan 1:16, namun dalam penelitian menggunakan 1:14 karena masih dalam range 1:16.

\section{Penularan Ichthyopthirius multifiliis Dengan Kohabitasi}

Kohabitasi dilakukan selama 4 hari, dimana 7 ikan koi yang positif terserang I. multifiliis dimasukkan kedalam kolam kohabitasi. Kemudian hari kedua 100 ikan koi sehat yang akan diinfestasi dimasukkan ke dalam kolam kohabitasi. Kohabitasi berlangsung pada hari ketiga dan keempat. Pada hari ke empat dilakukan pemeriksaan ikan koi dengan 
menentukan tingkat infestasi ringan, sedang dan berat kemudian dilakukan dengan pengambilan darah. Selama pemeliharaan di kolam kohabitsi, ikan koi diberikan pakan pelet (dua kali sehari).

Pemeriksaan Parasit

Identifikasi parasit I. multifiliis dilakukan dengan scraping dengan scalpel di bagian yang terserang I. multifiliis yaitu sirip, ekor dan kepala. Menurut Yuasa dkk., (2003) mengatakan, bahwa hasil scraping diletakkan kaca preparat dengan setetes aquades dan diberi kaca penutup kemudian dilakukan pengamatan dengan mikroskop cahaya dari pembesaran rendah sampai besar (100-400x).

Tingkat infestasi I. multifiliis digolongkan berdasarkan jumlah I. multifiliis yang menginfestasi ikan koi yaitu jumlah parasit ringan 1-5, pada tingkat infestasi sedang 6-10 dan lebih dari 11 parasit pada infestasi berat dalam slide (Margolis et al., 1982 dalam Akter dkk., 2007). Penggolongan tingkat infestasi I. multifiliis dilakukan dengan cara Scraping dan dilakukan sekali pengambilan di bagian yang terserang. Pengaruh kerusakan yang berbeda disebabkan karena tingkat infestasi yang berbeda (Kabata, 1985).

Pemeriksaan Leukosit Ikan

Lucky (1977) dalam Salasia dkk., (2001) menyatakan, bahwa pengambilan darah diambil kirakira $0,5 \mathrm{ml}$ lewat arteri caudalis. Pengambilan darah dengan spuit $1 \mathrm{ml}$ yang sudah diberi Ethylene Diamine Tetra Acetic Acid (EDTA) kemudian jarum ditusukkan cukup dalam melalui garis lateralis, pembuluh darah berada tepat di bawah vertebra. Ulasan darah dilakukan menurut metode Dalimunthe (2006) dalam Prabowo (2009), yaitu ulasan darah yang sudah kering difiksasi dengan menggunakan methanol selama 3 menit kemudian dikeringkan, selanjutnya diwarnai dengan giemsa $20 \%$ selama 15 menit dan dikeringkan. Setelah itu dicuci dengan menggunakan air kran yang mengalir dan biarkan kering oleh udara. Hasil ulasan darah diamati di bawah mikroskop dengan pembesaran 1000 kali.

Menurut Bijanti (2005) menyatakan, bahwa leukosit ikan koi dengan pewarnaan giemsa 20\% akan terlihat gambaran leukosit. Leukosit dari agranulosit terdiri dari limfosit dan monosit. Gambaran limfosit yaitu memiliki inti sel besar berbentuk bulat. Gambaran monosit yaitu berukuran besar dengan bentuk tidak teratur.

Leukosit dari granulosit terdiri dari neutrofil, eosinofil dan basofil. Gambaran neutrofil yaitu memiliki bentuk sel oval dengan sitoplasma bergranula dan inti sel eksentrik. Inti dapat terlihat dengan 2 atau 3 lobus. Gambaran eosinofil yaitu berbentuk bulat dengan inti sel kadang eksentrik. Sedangkan gambaran basofil jarang sekali didapatkan cenderung tidak tampak dengan pengecatan giemsa (Bijanti, 2005)

Penghitungan leukosit dilakukan dengan cara cross sectioned atau penghitungan leukosit yang dimulai dari bagian tepi ulasan darah dengan cara mengular hingga diperoleh 100 sel leukosit kemudian dinyatakan dalam persen (\%) (Svobodova dan Vykusova, 1991).

$$
\text { Jumlah leukosit total }(\%)=\frac{\text { komponen sel leukosit }}{100} \times 100 \%
$$

Parameter Pengamatan

Parameter utama yang diamati adalah gambaran leukosit berupa jumlah masing-masing komponen leukosit yaitu limfosit, monosit, neutrofil, eosinofil dan basofil ikan koi normal (sehat) serta terinfestasi I. multifiliis dengan tingkat infestasi ringan, sedang dan berat yang dinyatakan dalam persen dan parameter penunjang meliputi pengamatan gejala klinis dan kualitas air, yaitu suhu dan $\mathrm{pH}$ yang diukur selama perlakuan.

\section{Analisis Data}

Data hasil penelitian dianalisis secara deskriptif, merupakan metode atau alat analisis yang biasa digunakan untuk menyederhanakan data agar mudah dipahami. Penyajiannya bisa dalam bentuk tabel, baik tabel frekuensi maupun tabel silang atau dalam bentuk grafik, diagram seperti diagram batang dan kurva (Setiawan, 2005).

Data yang diperoleh berupa data gambaran leukosit berupa jumlah masing-masing komponen leukosit (limfosit, monosit, eosinofil, neutrofil dan basofil) ikan koi normal dan leukosit ikan koi yang terserang I. multifiliis pada tingkat infestasi ringan, sedang dan berat, pengamatan gejala klinis dan kualitas air yaitu suhu dan $\mathrm{pH}$.

\section{Hasil dan Pembahasan}

Hasil Penelitian

Hasil identifikasi menunjukkan bahwa $I$. multifiliis yang ditemukan adalah stadium trophozoit dengan ciri morfologi berbentuk oval, ukuran panjang 0,5-1 mm, tubuh dikelilingi silia dan disetiap individu I. multifiliis memiliki makronukleus berbentuk tapal kuda dan mikronukleus yang kecil, trophozit yang ditemukan sama dengan ciri-ciri morfologi yang dikatakan oleh Post (1987). 
Pemeriksaan gambaran leukosit, berupa jumlah masing-masing komponen leukosit (limfosit, monosit, neutrofil, eosinofil), mengunakan 5 ekor ikan untuk masing-masing derajat infestasi $I$. multifiliis ringan, sedang dan berat. Hal ini sesuai dengan pendapat Supriyadi (2004) yaitu pengambilan jumlah sampel ikan antara 5-10 ekor ikan dari populasi dalam satu kolam.

Anderson dan Siwicki (1993) dalam Syawal dkk., (2008), menyatakan, bahwa peningkatan jumlah leukosit dapat dijadikan tanda adanya infestasi faktor parasit dan stres. Peningkatan jumlah leukosit (limfosit, monosit, neutrofil dan eosinofil) menunjukkan adanya respon perlawanan tubuh terhadap agen penyebab penyakit. Data ratarata persentase jumlah limfosit yang diperoleh selama penelitian pada ikan koi sehat (kontrol) yaitu $89.60 \%$ dan jumlah persentase limfosit mengalami penurunan pada infestasi I. multifiliis ringan, sedang dan berat yaitu $86.20 \%, 79.40 \%$ dan $75.2 \%$.

Hasil rata-rata persentase jumlah monosit pada ikan sehat (kontrol) rata-rata persentase jumlah monosit yang diperoleh selama penelitian yaitu 4.00 $\%$ dan rata-rata persentase jumlah monosit mengalami kenaikan pada infestasi I. multifiliis ringan, sedang dan berat yaitu $5.40 \%, 5.60 \%$ dan $6.60 \%$.

Data rata-rata persentase jumlah neutrofil pada penelitian ini didapatkan hasil, pada ikan sehat (kontrol) rata-rata persentase jumlah neutrofil yang diperoleh selama penelitian yaitu $5.00 \%$ dan ratarata persentase jumlah neutrofil mengalami kenaikan pada infestasi I. multifiliis ringan, sedang dan berat yaitu $6.40 \%, 11.20 \%$ dan $11.60 \%$.

Hasil rata-rata persentase jumlah eosinofil pada penelitian ini didapatkan hasil, pada ikan sehat (kontrol) rata-rata persentase jumlah eosinofil yang diperoleh selama penelitian pada ikan sehat (kontrol) eosinofil yaitu $1.40 \%$ dan rata-rata persentase jumlah eosinofil mengalami kenaikan pada infestasi I. multifiliis ringan, sedang dan berat yaitu $2.00 \%$, $3.60 \%$ dan $5.60 \%$.

Kualitas Air

Pengukuran kualitas air (suhu dan $\mathrm{pH}$ ) pada saat kohabitasi antara ikan sehat dengan ikan yang positif I. multifiliis saat pengambilan sampel menunjukkan bahwa kualitas air yaitu suhu memiliki rata-rata $24-26^{\circ} \mathrm{C}$ dan $\mathrm{pH}$ kolam kohabitasi rata-rata 8.
I. multifiliis merupakan ektoparasit pada ikan air tawar yang menyerang lapisan kulit dan sirip ikan. Penularan ikan yang terinfestasi $I$. multifiliis pada ikan sehat dapat terjadi secara kontak langsung dengan tomit atau theront. Infestasi $I$. multifiliis dapat dilakukan dengan metode kohabitasi pada waktu dan tempat tertentu, sesuai dengan pendapat Mahasri (2007), bahwa infestasi buatan dapat dilakukan dengan kohabitasi.

Kualitas air selama penelitian terutama suhu juga merupakan faktor penting dalam penularan ikan yang terinfestasi I. multifiliis dengan ikan sehat. Suhu air di kolam kohabitasi yaitu $24-26^{\circ} \mathrm{C}$ dimana $I$. multifiliis dapat berkembangbiak dengan baik sehingga penularan dapat berlangsung dengan cepat. Hal ini sesuai dengan Durborrow dkk., (1998) bahwa serangan I. multifiliis terhadap ikan sehat akan terjadi lebih cepat pada suhu dingin.

Leukosit merupakan sel darah yang berperan dalam sistem kekebalan tubuh. Leukosit membantu membersihkan tubuh dari benda asing, termasuk invasi patogen melalui sistem tanggap kebal. Ikan yang sakit akan menghasilkan banyak leukosit untuk memfagosit bakteri dan mensintesis antibodi (Moyle dan Cech, 2004).

Fujaya (2004) menyatakan, bahwa limfosit dalam tubuh ikan tidak bersifat fagosit tetapi memegang peranan penting dalam pembentukan antibodi, berkurangnya jumlah limfosit dapat menurunkan konsentrasi antibodi dan menyebabkan meningkatnya serangan penyakit. Hasil penelitian menunjukkan rata-rata persentase jumlah limfosit ikan sehat (kontrol) dengan ikan yang terinfestasi $I$. multifiliis terjadi penurunan jumlah limfosit. Menurut Stoskopf (1992) dalam Prabowo (2009) menyatakan bahwa penyakit dapat menimbulkan terjadinya lymphopenia atau menurunnya jumlah limfosit.

Weir (1990) dalam Jaya dkk., (2007) menjelaskan, bahwa makrofag merupakan bagian dari monosit yang matang berperan utama dalam memakan organisme kemudian dihancurkan. Ratarata persentase jumlah monosit ikan sehat (kontrol) dengan ikan koi yang terinfestasi I. multifiliis pada derajat infestasi ringan, infestasi sedang dan infestasi berat mengalami peningkatan. Jumlah monosit semakin tinggi pada infestasi berat, hal tersebut diduga monosit dapat menghancurkan organisme $I$. multifiliis yang menginfestasi ikan koi. 
Rata-rata persentase jumlah neutrofil ikan sehat (kontrol) dengan rata-rata persentase jumlah neutrofil mengalami kenaikan pada saat terinfestasi $I$. multifiliis ringan, sedang dan berat. Neutrofil berfungsi untuk mempertahankan tubuh dari partikel berbahaya terutama bakteri (Gandasoebrata (1999) dalam Sunarno (2007)).

Macdonald et al., (2001) dalam Saptanto (2004) mengatakan, infestasi parasit juga dapat memacu peningkatan eosinofil. Hasil penelitian menunjukkan infestasi parasit dapat meningkatkan jumlah eosinofil terlihat bahwa rata-rata persentase jumlah eosinofil ikan koi sehat (kontrol) dengan ratarata persentase jumlah eosinofil pada ikan yang terinfestasi I. multifiliis ringan, sedang dan berat. Eosinofil semakin meningkat ketika terjadi infestasi I. multifiliis. Hal ini sesuai dengan pendapat Robert (1989), bahwa eosinofil merupakan jenis leukosit yang berhubungan dengan infeksi parasit dengan demikian meningkatnya eosinofil menandakan banyaknya parasit.

Hasil penelitian menunjukkan adanya peningkatan jumlah monosit dan neutrofil. Hal ini sesuai dengan Sopinsa (1985) dalam Dias et al., (2007), bahwa komponen leukosit terutama monosit dapat menghancurkan organisme patogen pada ikan yang terinfestasi parasit.

Dias et al., (2007) menyatakan, bahwa sulit untuk menguraikan perubahan jumlah sel darah terhadap kekebalan tubuh ikan terhadap parasit, karena fungsi yang tepat dari setiap sel darah masih sedikit untuk diketahui. Selain itu untuk menginterprestasi sel darah ini dapat menyebabkan kesalahan, ketika akan mencoba untuk membuat kesimpulan mengenai ikan yang mengalami stres dengan ikan yang terserang parasit. Namun, ketika ikan terserang oleh parasit dalam tingkat infestasi yang berbeda, telah diinformasikan akan terjadi limfositosis yang disertai dengan neutrofil dan monositosis.

Keadaan kualitas air kohabitasi yang menjadi tempat hidup ikan koi yang diambil sebagai sampel. Data kualitas air pada kolam kohabitasi masih berada dalam kisaran nilai optimum untuk budidaya ikan ikan koi. Kualitas air kolam kohabitasi masih dalam batas toleransi sehingga tidak terlalu berpengaruh pada kesehatan ikan koi.

\section{Kesimpula}

Ikan koi yang terinfestasi I. multifiliis pada derajat infestasi ringan, sedang dan berat dapat menyebabkan terjadinya perubahan gambaran leukosit berupa jumlah masing-masing komponen leukosit (limfosit, monosit, neutrofil dan eosinofil), hal ini disebabkan adanya tingkat infestasi yang berbeda. Jumlah persentase komponen limfosit mengalami penurunan dari infestasi ringan, sedang dan berat dibandingkan dengan ikan sehat (normal) sedangkan persentase komponen leukosit monosit, neutrofil dan eosinofil mengalami peningkatan pada infestasi ringan, sedang dan berat dibandingkan dengan ikan sehat (normal).

Hasil pemeriksaan pemeriksaan gambaran darah ikan berupa jumlah masing-masing komponen leukosit ikan (limfosit, monosit, neutrofil dan eosinofil) yang terinfestasi I. multifiliis dapat digunakan untuk mendiagnosis status kesehatan ikan yang terserang penyakit. Selain itu dalam penghitungan leukosit juga perlu dilakukan dengan menggunakan haemocytometer sehingga dapat mendukung penghitungan dengan metode diferensial leukosit.

\section{Daftar Pustaka}

Akter, M. A., M. D. Hossain dan M. R. Rahman. 2007. Parasitic Disease of Exotic Carp in Bangladesh. Department of Fisheries, University of Rajshahi. Bangladesh.

Bijanti, R. 2005. Hematologi Ikan (Teknik Pengambilan Darah Dan Pemeriksaan Hematologi Ikan). Buku Ajar. Bagian Ilmu Kedokteran Dasar Veteriner, Fakultas Kedokteran Hewan. Universitas Airlangga.

Dias, T, M. F. R, M. F. R, Moraes, M. L. Martins dan A. E. Santana. 2002. Haematological changes in A.E. 2002 Haematological changes in Oreochromis niloticus Linnaeus, 1758 (Osteichthyes: Cichlidae) with gill ichthyophthiriasis and saprolegniosis. Boletim do Instituto de Pesca, São Paulo, 28: 1-9

Dogiel. V.A, G. K Petrushevski and Y. I Polyanski. 1970. Parasitology of Fishes. TFA A berdeen.

Durborow, Mitchell and Crosby. 1998. Ich (White Spot Disease). South Regional Aquaculture Centre.

Galeriukm. 2010. Meraih Keuntungan Budidaya Ikan Hias. http://galeriukm.web.id/peluangusaha/meraih-keuntungan-budidaya-ikanhias

Huda, S. 2008. Penyakit Pada Ikan Air Tawar. Dinas Kelautan dan Perikanan Air Tawar Propinsi 
B a n t e n. h t t p : / / w w w. d k p banten.go.id/news/?p=47.

Jaya, F., L. E. Radiati, K. U. Alawwaly dan U. Kalsum. (2007). Pengaruh Pemberian Ekstrak Propolis Terhadap Sistem Kekebalan Seluler Pada Tikus Putih (Rattus

norvegicus). Fakultas Perternakan Universitas Brawijaya, Malang.

Kabata, Z. 1985. Parasites and Disease of Fish Cultured in The Tropics. Philadelphia: International Development Research Council.

Mahasri, G. 2007. Protein Membran Imunogenik Zoothamnium penaei sebagai Bahan Pengembangan Imunostimulan pada Udang Windu (Penaeus monodon Fabricus) Terhadap Zoothamniosis. Disertasi Program Pascasarjana Airlangga. 284 hal.

Moyle, P.B and J.J Cech. 2004. Fish An Introduction To Ichthyology Fifth Edition. Prentice Hall: New Jersey.

Prabowo, M. A. 2009. Gambaran Leukosit Darah Ikan Mas Koki (Carassius auratus) setelah Diinfestasi Argulus Japonicus. Skripsi Universitas Airlangga. Surabaya.

Post, George. 1987. Fish Health. United States of Amerika. TFH Publication. 182-183 hal.

Prayitno, S.B., Taukhid, Maskur dan Fatmah. 2003. Penyakit Virus Insang Membusuk (Koi Herpes Virus) pada Budi Daya Mas dan Koi. Departemen Perikanan dan Kelautan. Jakarta.

Roberts, R. J. 1989. Fish Pathology. Baillere Tindall. London. England. 467p.

Sinartani. 2010. Meraih Untung dari Bisnis Ikan Koi. Jakarta.

Salasia, S. I. A., D. Sulanjari dan A. Ratnawati. 2001. Studi Hematologi Ikan Air Tawar. Bagian Patologi Klikik Fakultas Kedokteran Hewan. Universitas Gajah Mada.
Saptanto, A. 2004. Eosinifilia dan Kepadatan Parasit Malaria pada Anak Sekolah di Daerah Endemis Malaria. Tesis Program Pendidikan Dokter Spesialis I Bagian Ilmu Kesehatan Anak. Universitas Diponegoro. Semarang.

Sunarno. 2007. Efek Phyllanthus Niruri pada Prosentase Neutrofil, Koloni Bakteri Limpa dan Histopatologi Hepar Mencit Balb/C yang Diinfeksi Salmonella Typhimurim. Tesis Program pascasarjana. Universitas Diponegoro. Semarang.

Syawal, H. Syafriadiman dan S. Hidayah. 2008. Pemberian Ekstrak Kayu Siwak (Salvadora persica L.) Untuk Meningkatkan Kekebalan Ikan Mas (Cyprinus carpio L.) Yang Dipelihara Dalam Keramba. Jurusan Budidaya Perairan, Fakultas Perikanan dan Ilmu Kelautan. Universitas Riau (UNRI), Pekanbaru. 45-48 hal.

Wijanarko, P. Y. 2010. Teknik Pembesaran Ikan Koi Menggunakan Sistem Resirkulasi Air Di Eko dan Nomi Koi Farm Semarang. Fakultas Perikanan dan Kelautan. Universitas Airlangga. Surabaya.

Wahyuni, I. 2007. Ikan Botia si Cantik dan Penyakitnya. Pusat Karantina Ikan. Departemen Kelautan dan Perikanan. Jakarta.http://www.puskari.dkp.go.id/files/p ublikasi/majalah/infokarikan\%20vol\%204 $\% 20$ no\%202\%20agustus\%202007.pdf

Yuasa, K., N. Panigoro. M. Bahnan dan E.D. Kholidin. 2003. Panduan Diagnosa Penyakit Ikan. Balai Budidaya Air Tawar. Jambi. 